\title{
Effects of Concentrate Supplementation to Holstein Heifers Grazed at a High Stocking Rate on Intensively Managed Pastures from Breeding Age to Parturition ${ }^{1}$
}

\author{
P. F. Randel and N. Mendoza ${ }^{2}$
}

\begin{abstract}
Three groups of 24 Holstein heifers of breeding age were grazed at 5 animals per ha on intensively managed pastures at the Isabela Substation. Treatments differed in concentrate supplementation as follows: T1, none (control); T2, $1.8 \mathrm{~kg}$ per head daily continuously; and T3, $4.5 \mathrm{~kg}$ daily to heifers beyond 5 months pregnant. About $2 \mathrm{~kg}$ per head daily of poor-quality hay was supplied when drought reduced pasture herbage availability. Groups remained intact for 309 days; thereafter, heifers nearing parturition were removed periodically until final termination after $\mathbf{4 4 9}$ days.

Respective mean liveweights increased from 339,334 , and $330 \mathrm{~kg}$ initially to 468,517 , and $465 \mathrm{~kg}$ after 309 days, representing daily increments of .42, .58 , and .44 kg; treatments T2 and T3 combined surpassed T1, and T2 surpassed T3 $(\mathrm{P}<.01)$. Corresponding gains including data beyond 309 days, of $.46, .59$ and $.50 \mathrm{~kg}$, also differed $(\mathrm{P}<.01)$. Treatments significantly affected final measures of heart girth and body length $(P<.01)$, but not wither height. In T2 and T3, 9.64 and $4.25 \mathrm{~kg}$ of concentrate were employed per kilogram extra gain (relative to control). T2 resulted in earliest establishment of pregnancy $(P<.01)$. Follow-up observation was possible on only 18 animals transferred to the Lajas Substation; those fed concentrate prepartum (T2 and T3) produced $10 \%$ more milk in first location and had lower attrition rate than controls. Concentrate supplementation beyond breeding age is an expensive means of accelerating growth and achieving earlier calving, but may be necessary for optimum postpartum performance.
\end{abstract}

\section{INTRODUCTION}

A series of experiments on raising systems for dairy replacement heifers, emphasizing maximum use of intensively managed pastures, has been conducted in recent years by this Station. Grazing alone, at stocking rates ranging from 2.5 to 5 animals per ha, or grazing with only a small complement of concentrate, sustained adequate growth of Holstein heifers, commencing at about 9 mo of age and 150 to $200 \mathrm{~kg}$ liveweight $(1,2,5)$.

Most of the studies in question lasted 12 mo or longer and resulted in final liveweights in excess of $400 \mathrm{~kg}$. Since extensive changes in physiological status and nutrient requirements of growing animals occur over such long periods, greater efficiency might be achieved by altering the feeding system at different stages of growth. One logical division would be between prebreeding and breeding stage and from breeding until first

\footnotetext{
${ }^{1}$ Manuscript submitted to Editorial Board November 8, 1982.

${ }^{2}$ Animal Nutritionist and Research Assistant, Agricultural Experiment Station, Mayagüez Campus, University of Puerto Rico, Lajas and Isabela, respectively.
} 
calving. This present trial focused on the latter segment of the growth curve, following a previous study with the same Holstein heifers, and emphasized preparation for first lactation.

\section{MATERIALS AND METHODS}

Seventy-eight Holstein heifers, mostly 8 to 9 mo of age and weighing at least $135 \mathrm{~kg}$, were assembled at the Isabela Substation November 1977. The majority were borrowed from two commercial herds nearby and the rest were property of the Station. First, they were employed in an experiment lasting until July 1978, in which three different schedules of concentrate supplementation of grazing were compared. Animal growth differed little among treatments. Mean liveweight increased from $161 \mathrm{~kg}$ to $322 \mathrm{~kg}$ in 225 days, representing a .71-kg daily gain.

Upon completion of the previous experiment, 72 of the same animals were selected for use in the present study. They were stratified by liveweight into 24 trios and one heifer from each was assigned at random to each of three new treatment groups. Previous to starting the present experiment, fences in the pastures were adjusted to form 12 paddocks of 1.2 ha each. Pasture herbage was predominantly guinea-grass (Panicum maximum Jacq.) and lesser proportions of pangola (Digitaria decumbens Stent) and malojillo (Brachiaria purpurascens (Raddi) Henr.). Fertilization rate was 2,270 $\mathrm{kg}$ annually of a 15-5-10 formula, divided into equal applications at a 3-mo interval. Stocking rate was 5 animals per ha in all treatments. Groups were rotated weekly among paddocks, each group grazing in all 12 enclosures during a complete cycle.

Treatments differed in schedule of concentrate supplementation as follows: T1, no supplement (control); T2, $1.8 \mathrm{~kg}$ per head daily of an $18 \%$ crude protein $(\mathrm{CP})$ commercial concentrate throughout the experiment; and T3, $4.5 \mathrm{~kg}$ per head daily of the same concentrate commencing after the fifth month of pregnancy. Supplementation of the T3 heifers that were most advanced in gestation began February 1979. Concentrate allowances were fed by group in two enclosed areas, each equipped with a feed bunk $9.6 \mathrm{~m}$ in length, located under a sheet metal roof.

Rainfall at the Isabela Substation was adequate for rapid herbage growth during the first 4 mo (July to October 1978), i.e., respective monthly totals were $137,240,182$, and $130 \mathrm{~mm}$. Thereafter, rainfall declined to $56,81,45,41$, and $0 \mathrm{~mm}$ during the 5 successive months from November 1978 to March 1979. Because of the high stocking rate and sparse rainfall during late winter and early spring, pasture herbage became critically short. From January 22 to April 16, poor quality grass hay from Lajas was used as a forage supplement. Bales were placed on the ground in paddocks where heifers were grazing. Although hay was not available continuously, hay intake is estimated to have been about 2 
kg per head daily during the period in question. The drought ended with $195 \mathrm{~mm}$ of rainfall in April and $269 \mathrm{~mm}$ in May, which resulted in abundant pasture regrowth within a few weeks. A calcium-phosphorus mineral supplement was employed beginning about 1 mo after commencing the experiment. It was provided free-choice at first, but luxury consumption made it necessary to limit the offering to $28 \mathrm{~g}$ per head daily thereafter.

Natural insemination began August 1978, with rebreeding as necessary until pregnancy was confirmed by rectal palpation. Most animals had conceived within 5 mo. One heifer from T2 was lost in August 1978, because of an unidentified disease; 2 others from T3 died the following January from insecticide poisoning. Substitutes for these three animals were selected from among the six heifers left over from the previous experiment which had been maintained meanwhile in similar pastures adjacent to the experimental paddocks.

Animals were weighed once every 4 weeks, in the mornings after a 2 hour stand without feed or water. Simultaneous measurements of heart girth, body length, and wither height were taken on three occasions: initially, after 169 days, and at final weighing. Groups remained intact for 309 days, until May 16, 1979. On this date, 1/3 of the animals, the eight from each group most advanced in pregnancy, were separated and placed temporarily in 3 of the 12 paddocks, thereby being eliminated from the rotation followed by the treatment groups (now 16 animals each). A few additional heifers near calving were removed from T1 and T2 on July 11, August 8, and September 5, until complete termination on October 3, 1979. During the final months (June to September) rainfall was 196, 129, 92, and $283 \mathrm{~mm}$, respectively.

Fifty four animals leaving the experiment were returned to their original farms, while 18 were added to the Lajas Substation herd. Most were shipped away shortly before parturition, but a few calved while still at the Isabela Substation. A follow-up of these animals as lactating cows was planned. Unfortunately, the necessary cooperation from the private farms was not obtained; thus only incomplete data could be gathered on the 18 animals at Lajas. These were all subjected to approximately the same management after calving. Their ration consisted of grazing on pastures that varied substantially in quality throughout the year plus an $18 \%$ CP concentrate, fed according to production based on daily milk weights. The first eight animals to calve also received condensed molasses solubles as a liquid supplement for several months during early lactation.

Data compiled during the experiment at Isabela were subjected to analysis of variance appropriate to a complete blocks design (3). The 2 degrees of freedom for treatments were used to test either the specific differences 1 vs $2+3$ and 2 vs 3 or 2 vs $1+3$ and 1 vs 3 , as appropriate. 


\section{RESULTS AND DISCUSSION}

Initial liveweight of the control group (T1) was $339.3 \mathrm{~kg}$ (table 1). This mean increased by $129.2 \mathrm{~kg}$ to $468.5 \mathrm{~kg}$ in 309 days, representing a relative increment of $38 \%$ and a daily gain of $.42 \mathrm{~kg}$. Growth of these heifers varied markedly among individual 4 -wk weighing intervals, the highest rate being $.83 \mathrm{~kg}$ daily in the 7th interval, from 26 December to 23 January. Liveweights observed on the latter date may have been inflated because of accumulation of gastrointestinal contents, since hay feeding had begun the previous day. Otherwise, most rapid gains by this group were $.56 \mathrm{~kg}$ daily in the $1^{\text {st }}$ interval and $.52 \mathrm{~kg}$ in both the $3^{\text {rd }}$ and $9^{\text {th }}$, while the slowest were $.06 \mathrm{~kg}$ and $.08 \mathrm{~kg}$ in the $5^{\text {th }}$ and $10^{\text {th }}$ intervals, respectively.

None of the T3 heifers received supplementation with concentrate until the $8^{\text {th }}$ weighing interval, thus during 7 periods this group's ration was also grazing alone, as in the control. During this pre-supplementation stage, daily gains by these heifers ranged from $.96 \mathrm{~kg}$ in the $1^{\text {st }}$ interval to $.09 \mathrm{~kg}$ in the $6^{\text {th }}$ and averaged $.40 \mathrm{~kg}$. These growth rates were lower than those obtained from grazing alone at the same stocking rate in previous studies, as reviewed by Bravo (1). However, the earlier experiments had begun with smaller heifers and thus lower stocking rates in terms of total biomass. Therefore, a stocking rate of 5 heifers of the present size per ha can be considered excessive during periods of suboptimal rainfall. Only seven heifers of T3 received appreciable amounts of concentrate during the first 309 days. Mean daily gains in the corresponding weighing intervals ( $8^{\text {th }}$ through $11^{\text {th }}$ ) were $.90, .23, .28$, and $.52 \mathrm{~kg}$, or $.49 \mathrm{~kg}$ for the four together. When averaged over-all, concentrate was fed on only $6.5 \%$ of the animal-days and daily intake was .29 kg in T3. Mean gain by this group was $.44 \mathrm{~kg}$, or only $.02 \mathrm{~kg}$ greater daily than the control (table 1).

Continuous supplementation with $1.8 \mathrm{~kg}$ of concentrate daily (T2) produced satisfactory growth. During 309 days, mean liveweight increased from $334.4 \mathrm{~kg}$ to $516.6 \mathrm{~kg}$. This total gain of $178.8 \mathrm{~kg}$ represents a relative increase of $53 \%$ and $.58 \mathrm{~kg}$ daily (table 1). The latter figure agrees well with the daily gain of $.61 \mathrm{~kg}$ obtained with essentially the same treatment in a recent experiment at Corozal (6). Treatments were a significant $(\mathrm{P}<.01)$ source of variation in liveweight gain during 309 days, but blocks (initial trios of heifers) were not. In fact, test of treatments was more strongly significant when sum of squares for blocks was not removed from that for error and the design was treated as completely randomized, rather than as randomized blocks. In either case, $\mathrm{T} 1$ was inferior $(\mathrm{P}<.01)$ in growth rate to $\mathrm{T} 2+\mathrm{T} 3$, as was $\mathrm{T} 3$ to $\mathrm{T} 2$.

When data obtained after 16 May were included, mean days on 
TABLE 1.-Liveweight responses during 309 days and for the whole experiment, and stage of pregnancy after 309 days of experimentation

\begin{tabular}{|c|c|c|c|c|c|c|c|c|c|}
\hline \multirow[t]{2}{*}{ Treatment } & \multicolumn{3}{|c|}{$\begin{array}{c}\mathrm{T}-1 \\
\text { Grazing only }\end{array}$} & \multicolumn{3}{|c|}{$\begin{array}{c}\mathrm{T}-2 \\
1.8 \mathrm{~kg} \text { concentrate } \\
\text { daily continuously }\end{array}$} & \multicolumn{3}{|c|}{$\begin{array}{c}\mathrm{T}-3 \\
4.5 \mathrm{~kg} \text { concentrate } \\
\text { daily after } 5 \text { months } \\
\text { pregnant }\end{array}$} \\
\hline & Mean & $\mathrm{SE}^{1}$ & $\mathrm{CV}^{1}$ & Mean & $\mathrm{SE}$ & $\mathrm{CV}$ & Mean & SE & $\mathrm{CV}$ \\
\hline Initial liveweight $(\mathrm{kg})$ & 339.3 & 6.5 & 9.4 & 334.4 & 6.7 & 9.8 & 330.1 & 8.1 & 12.0 \\
\hline Liveweight at 309 days $(\mathrm{kg})$ & 468.5 & 6.5 & 6.8 & 516.6 & 8.5 & 8.1 & 464.7 & 11.6 & 12.2 \\
\hline Daily gain during 309 days $(\mathrm{kg})$ & .418 & .015 & 17.1 & .580 & .019 & 16.3 & .442 & .024 & 26.9 \\
\hline Final liveweight $(\mathrm{kg})$ & 513.8 & 7.1 & 6.8 & 542.0 & 9.2 & 8.3 & 529.1 & 11.7 & 10.8 \\
\hline Daily gain over-all (kg) & .455 & .013 & 14.5 & .593 & .017 & 14.0 & .503 & .016 & 15.4 \\
\hline Days pregnant at 309 days & 165.7 & 14.8 & 43.8 & 201.8 & 13.0 & 31.5 & 122.3 & 16.0 & 64.2 \\
\hline
\end{tabular}

${ }^{1} \mathrm{SE}=$ standard error; $\mathrm{CV}=$ coefficient of variation. 
experiment for animals of T1, T2, and T3 were 386, 346, and 402; total liveweight increases were $174.5,207.6$, and $199.0 \mathrm{~kg}$; and final liveweights $513.8,542.0$, and $529.1 \mathrm{~kg}$ (table 1). Corresponding daily gains were .46, .59 , and $.50 \mathrm{~kg}$. Again, treatments had significant $(\mathrm{P}<.01)$ effects and the 2 specific treatment comparisons yielded differences $(\mathrm{P}<.01)$. Thus, supplementation was clearly beneficial in promoting growth. However, the control showed improvement during latter stages of the experiment, when pasture herbage had recovered from its earlier poor condition and was abundant again.

Total amount of concentrate employed in $\mathrm{T} 2$ was $6,855 \mathrm{~kg}$, and additional liveweight gain over the control was $711 \mathrm{~kg}$. Thus, 9.64 units of concentrate were consumed per unit of additional gain, a very inefficient conversion in either biological or economic terms. Daily supplementation averaged $.81 \mathrm{~kg}$ per head over the whole experiment in T3. In this case, $3,639 \mathrm{~kg}$ of concentrate resulted in $857 \mathrm{~kg}$ of additional gain, resulting in a ratio of 4.25 . This conversion figure represents a decided improvement over $\mathrm{T} 2$, but still constitutes a costly means of enhancing heifer growth. With concentrate priced at about $\$ .22 / \mathrm{kg}$ at the time, feed costs increased $\$ .94 / \mathrm{kg}$ of additional gain in T3.

Heifers of T2 conceived sooner than those of the other treatments, as shown by the mean number of days pregnant (201.8) after 309 days of experimentation (table 1). The other heifers, especially those of 'T3, were at an earlier mean stage of pregnancy after 309 days and showed greater within-group variability in this criterion (table 1). Concentrate supplementation during early months of the study was therefore associated with earlier $(\mathrm{P}<.01)$ establishment of pregnancy; it is not evident, however, why T3 heifers should have been at a disadvantage $(\mathrm{P}<.05)$ relative to those of $\mathrm{T} 1$ ( 122.3 vs 165.7 days), since both groups were subjected to the same nutritional regime until the 5th mo of gestation.

Mean initial body measurements were nearly identical in T1 and T2, but slightly lower in T3 (table 2). By the end of period 7, 196 days later, heart girth had increased by $15.0,20.8$, and $15.2 \mathrm{~cm}$ in heifers of the three respective treatments. Increases in this body dimension were in the same proportion as corresponding liveweight increases in T1 and T2 (86.9 and $120.5 \mathrm{~kg}$ ), but this proportion was exceeded in $\mathrm{T} 3$, wherein liveweight gain was only $78.8 \mathrm{~kg}$. Heart girth was not measured again until final weighing of each heifer prior to leaving the experiment. Final treatment means showed a range of $4.6 \mathrm{~cm}$, from $192.4 \mathrm{~cm}$ to $187.8 \mathrm{~cm}$ for $\mathrm{T} 2$ and $\mathrm{T} 1$, respectively (table 2 ). Treatments were a significant ( $\mathrm{P}$ $<.01)$ ) source of variation in final heart girth; T2 and T3 combined surpassed $\mathrm{T} 1$ and $\mathrm{T} 2$ exceeded $\mathrm{T} 3(\mathrm{P}<.05)$.

Mean body length increased 9.7, 13.2 , and $12.0 \mathrm{~cm}$ in the three respective groups during the first 196 days of experimentation. Again T1 
and T2 showed the same proportional increase in this body dimension as in liveweight, but the discrepancy for T3 was still greater than that with heart girth. In spite of a limited range among groups in final body length of only $2.6 \mathrm{~cm}(140.9 \mathrm{~cm}$ to $137.3 \mathrm{~cm})$ (table 2), treatments had a significant effect $(\mathrm{P}<.01)$, the means of $\mathrm{T} 2$ and $\mathrm{T} 3$ exceeded the mean of T1 $(\mathrm{P}<.01)$; the mean of T2 exceeded that of T3 $(\mathrm{P}<.05)$. In height at withers, treatment means increased $7.9,8.2$ and $6.9 \mathrm{~cm}$, respectively, during the initial 196 days. Although this ranking of treatments was the same as for increases in liveweight, the changes were not reasonably proportional. Final height at withers did not differ significantly $(\mathrm{P}>.05)$ among treatments. Unlike final liveweight, final height was greater in T1 than in T3 (132.4 cm vs $131.5 \mathrm{~cm}$ ) (table 2). These data are consistent with previous reports, both from Puerto Rico (1) and Maryland (4), showing that heart girth is more closely associated with liveweight in

TABLE 2.-Initial and final heart girth, wither height and body length

\begin{tabular}{lccccccccc}
\hline \multicolumn{1}{c}{ Treatment } & Mean & $\begin{array}{c}\mathrm{T}-1 \\
\mathrm{SE}^{1}\end{array}$ & $\mathrm{CV}^{1}$ & Mean & $\begin{array}{c}\mathrm{T}-2 \\
\mathrm{SE}\end{array}$ & $\mathrm{CV}$ & Mean & $\mathrm{T}-3 \mathrm{SE}$ & $\mathrm{CV}$ \\
\hline $\begin{array}{l}\text { Heart girth } \\
\quad \text { Initial }\end{array}$ & & & & & & & & & \\
$\quad$ Final & 160.6 & 1.1 & 3.4 & 160.6 & 1.4 & 4.2 & 160.1 & 1.5 & 4.5 \\
$\quad \begin{array}{l}\text { Wither height } \\
\quad \text { Initial }\end{array}$ & 187.8 & 1.2 & 3.0 & 192.4 & 1.2 & 3.1 & 189.5 & 1.6 & 4.1 \\
$\quad$ Final & 122.1 & .5 & 2.2 & 121.8 & .8 & 3.2 & 120.9 & .8 & 3.2 \\
Body length & 132.4 & .6 & 2.2 & 133.7 & .8 & 3.0 & 131.5 & .7 & 2.6 \\
$\quad$ Initial & 125.3 & .7 & 2.9 & 125.1 & .6 & 2.2 & 124.8 & .9 & 3.4 \\
$\quad$ Final & 137.3 & .7 & 2.4 & 140.9 & .8 & 2.6 & 138.1 & 1.1 & 3.7 \\
\hline
\end{tabular}

${ }^{1} \mathrm{SE}=$ standard error; $\mathrm{CV}=$ coefficient of variation.

Holstein heifers than are the other body measurements in question. The present study, as well as earlier studies of Sanfiorenzo et al., cited by Bravo (1), suggest that body length (withers to pins) is also a fairly reliable indicator of liveweight. Wither height appears to be the least useful of the three body measurements in this regard.

Of the 18 heifers transferred to Lajas upon completing this experiment, eight were from T1 and five from both T2 and T3. Incidence of blind quarters at calving was unusually high among these animals, three controls and one T2 heifer were affected. One control heifer (different from the three cited) lactated for only 21 days before acute bloat caused her to stop eating and lactating. Six weeks later, this animal died of recurring bloat and traumatic gastroenteritis. This abbreviated lactation was excluded in calculating mean production of this group. One T2 heifer was sold while still lactating at 184 days postpartum. She was deemed 
infertile, after having had a stillborn calf, and then failing to come in heat thereafter. Milk production for 305 days was estimated by extrapolation of this animal's lactation curve. The 16 remaining animals completed their first lactation in the Lajas herd. On the basis of 7, 5 , and 5 records for the 3 respective treatments, and excluding days beyond the 305th, mean lactation duration and yield were as follows: 292 days and 2,756 kg; 290 days and 2,916 kg; and 301 days and 3,073 kg. One of the five T3 heifers in question had received no supplementation prepartum, because she was too early in pregnancy when the experiment ended. Excluding this animal, first-lactation milk production of the nine animals of $\mathrm{T} 2$ and $\mathrm{T} 3$ that did receive supplementation prior to calving was $10.2 \%$ higher than that of the seven controls.

Additional data are needed to permit firm conclusions, but the finding that heifers raised on grazing only had nearly as high first-lactation milk yields as those fed supplemental concentrates concurs with recent results at Corozal (6). Simón y Perdomo (7) in Cuba also reported that 3/4 Holstein-1/4 Zebu heifers raised on either grazing alone of fertilized pangolagrass at 5 animals/ha, or grazing plus $1 \mathrm{~kg}$ of concentrate daily during the dry season, gave first-lactation milk productions, after transfer to a commercial farm, of 1,275 and $1,450 \mathrm{~kg}$, respectively. Thus, supplementation prior to calving was associated with a nonsignificant $(\mathrm{P}>.05)$ $12 \%$ greater milk yield. In the same study (7), a third group, supplemented as heifers with both $1 \mathrm{~kg}$ of concentrate and molasses-urea ad libitum during dry season, had, surprisingly, the lowest first-lactation yield. Most evidence thus far indicates a slight boost in milk yield due to prepartum concentrate supplementation of heifers on tropical pastures, but this increase is achieved at considerable expense.

Another possible advantage of concentrate supplementation for replacement heifers is in regard to time; i.e., supplemented heifers develop faster and calve sooner. However, an alternative strategy is to sacrifice a certain amount of time, but eventually achieve the same development with forage-only feeding. Whether a saving in time to first calving or a saving in concentrates would constitute the greater economic benefit is a matter for analysis under the conditions of individual farms.

The most disturbing observation revealed from follow-up of the control heifers was their greater attrition rate. Before beginning a second lactation, four of eight control heifers had left the Lajas herd because of death or culling, for blind quarters or low production; the T3 animal that received no concentrate prepartum was also sold for infertility and lameness after a single lactation. No other losses prior to second lactation were registered in $\mathrm{T} 3$, while two $\mathrm{T} 2$ heifers were eliminated, one because of a blind quarter and mastitis, and the other because of infertility. Thus, only four of nine heifers raised on forage only, compared with seven of 
nine fed concentrates prepartum, had a second lactation in the herd. Indeed, all of the latter survived for a third lactation, which only two forage-only heifers did. It must be stressed again that these are limited data, but a greater rate of postpartum attrition among control heifers was also found in following-up the Corozal experiment (6). This point needs additional study. A shorter mean herd life, if proved to be a consistent result of raising dairy heifers on grazing alone, might not justify grazing alone, in spite of additional cost of supplements.

\section{RESUMEN}

Tres grupos de 24 novillas Holstein, de edad para aparearse, se asignaron a raciones basadas en pasto a razón de cinco novillas por hectárea en 12 predios de 1.2 ha cada uno, sembrados mayormente de yerba guinea (Panicum maximum Jacq.) e intensamente administradas en la Subestación de Isabela. En los tres tratamientos, la suplementación con alimento concentrado fue: 1) ninguno (testigo); 2) $1.8 \mathrm{~kg}$ diarios por cabeza continuamente; y 3) $4.5 \mathrm{~kg}$ diarios para novillas con 5 meses o más de preñez. Se suplió heno de baja calidad a razón de aproximadamente $2 \mathrm{~kg}$ diarios por cabeza durante 3 meses cuando, debido a la sequía, el forraje pratense era escaso y, además $28 \mathrm{~g}$ diarios continuamente de un suplemento mineral. Durante 309 dias los grupos se mantuvieron intactos. De ahi en adelante se retiraron del experimento periódicamente conjuntos de novillas próximas a parir, hasta terminar el experimento a los 449 días.

El peso vivo medio aumentó en los tres respectivos tratamientos de 339, 334 y $330 \mathrm{~kg}$ inicialmente a 468, 517 y $465 \mathrm{~kg}$ luego de 309 días, representando ganancias diarias de $.42, .58$ y $.44 \mathrm{~kg}$. Al comparar los tratamientos 2 y 3 combinados contra el I y el 2 contra el 3 , las diferencias en tasa de ganancia fueron significativas $(P<.01)$. Al incluir también los datos recopilados luego de los 309 días, las ganancias correspondientes fueron $.46, .59$ y $.50 \mathrm{~kg}$ diarios, valores que difirieron significativamente ( $P$ $<$.01). Los tratamientos afectaron $(\mathrm{P}<.01)$ el perímetro torácico y la longitud del cuerpo, pero no la altura a la cruz. En los tratamientos 2 y 3 se emplearon 9.64 y $4.25 \mathrm{~kg}$ de alimento concentrado/kg de aumento adicional en peso vivo con relación al testigo. En promedio, las novillas del tratamiento 2 estaban más adelantadas $(P<.01)$ en preñez luego de 309 dias.

No fue posible dar seguimiento a la mayoría de estas novillas luego de devolverlas a dos fincas comerciales, pero entre las 18 transferidas a la Subestación de Lajas, las que recibieron alimente concentrado antes del parto produjeron $10 \%$ más leche en la primera lactancia con menos bajas que las criadas con forrajes solamente. Por ende, el suministro de alimento concentrado a novillas de edad para apareamiento es un medio costoso 
tanto para acelerar el crecimiento como para adelantar la edad al parir, pero tal vez sea necesario para un comportamiento óptimo luego del parto.

\section{LITERATURE CITED}

1. Bravo-Ramos, L., 1981. Evaluación de sistemas de alimentación para la crianza de novillas de reemplazo, M.S. Thesis. Mayagüez Campus, Univ. P.R.

2. Carlos, I. and J. Vélez, 1978. Evaluation of different feeding systems for dairy heifers, J. Agric. Univ, P.R. 62 (4): 311-20.

3. Cochran, W. G. and G. M. Cox, 1968. Experimental Designs, 2nd ed, John Wiley \& Sons, Inc., New York.

4. Matthews, C. A., W. W. Swett and R. E. McDowell, 1975. External form and internal anatomy of Holsteins and Jerseys, J. Dairy Sci. 58 (10): 1453-75.

5. Mendoza, R., 1977. Comparación de tres sistemas de alimentación en la crianza de novillas de reemplazo, Esta. Exp. Agric. Univ. P.R. Publ. 115.

6. Randel, P. F. and J. Vélez-Santiago, 1982. Effects of grazing alone or with three schedules of supplementation from breeding age to first parturition in Holstein heifers, Submitted to J. Agric. Univ. P.R.

7. Simon, L. and A. Perdomo, 1979. Efecto de tres sistemas de alimentación sobre el comportamiento de hembras bovinas en crecimiento, Pastos y Forrajes 2 (2): 26572. 